\title{
Social Media Usage and Its Influence on Students' Choice of Tertiary Institutions in Ghana
}

\author{
Afako Jephthah Kwame (MBA) ${ }^{1^{*}} \quad$ Afako Jeremiah Kweku (MA) $)^{1,2}$ \\ 1.School of Management, Jiangsu university, 301, Xuefu Rd. Zhenjiang, P.R. China \\ 2.Distant learning collage, University of Education, Winneba, P. O. Box 25, Winneba, Ghana
}

\begin{abstract}
Tertiary Institutions among other businesses have been promoting their services through various conventional media which can be considered as an integrated form of communication. On the other hand, with the incorporation of the modern technologies into individual and professional lives, tertiary cannot only communicate effectively with their target audience, but they can also use social media to disseminate information and obtain feedback.Using a quantitative research approach, this research identified the social media channels students use to search for tertiary institutions, examined the various social media platforms students actively engage in, how the use of social media influence students' tertiary institutions decision-making process and identified other factors that influence students' choice of tertiary institutions. Results showed that respondents heavily rely on university website to search for tertiary institution information even though they are very active on WhatsApp, spending over 2 hours daily. The findings of this research adds on to existing research on consumer decision making with respect to their choice of tertiary institutions. It also helps authorities of various tertiary institutions, to improve on their social media platform activities and also develop communication strategies in other to attract potential students through the various social media platforms. It might serve as the required cause for those institutions that have no presence at all on social media to establish one since prospective students might make use of such handles in selecting schools.
\end{abstract}

Keywords: Social Media, Tertiary Institutions, Ghana

DOI: $10.7176 / \mathrm{EJBM} / 11-30-07$

Publication date:October $31^{\text {st }} 2019$

\section{Introduction}

With the unavoidable incorporation of the Internet into individual and professional lives, marketers are scrambling to find the right spot to be in cyberspace (Keller, 2013). However, the emergence of social media has created a new and wide landscape for marketers to find the right spot to interact effectively with their customers as well as prospective customers on the internet. The term "social media" has basically been viewed in the public circle as a means of connecting people globally and creating a platform that allows interactions among them. However, many scholars have defined social media in different ways that has provided an in-depth understanding of what social media actually entails.

According to Fotis, Buhalis, and Rossides, (2012), social media can be defined as "group of internet based applications that are built on ideological and technological foundations of Web 2.0 and that allow the creation and exchange of User Generated Content. Social media can also be defined as online platforms that people use to share opinions and experiences including photos, videos, music and perceptions with each other. Social media platforms are categorized in eight main titles: social networking sites, blogs, micro blogs, content sharing sites, wikis, social bookmarking sites, podcasts and forums. (N Gizem, Secil, \& Evrin, 2013).

Today, social media has immensely increased in popularity among internet users. According to the 2016 internet live statistics, there are close to $\mathbf{3 . 5}$ billion internet users globally with an internet penetration of about $\mathbf{4 6 \%}$ of global population, a growth difference of $\mathbf{3 \%}$ from 2015. Out of these global internet users, Facebook remains the top network for membership (84\%) with over 1.79 billion monthly Facebook users which is $16 \%$ increase year over year. Twitter hosts over $\mathbf{3 0 9}$ million active daily users and YouTube users view over $\mathbf{2 . 6}$ billion videos per day. This is clearly evident that, with the growth of the internet, online social networks such as; Facebook, Twitter and YouTube have become very important communication channels marketers can use to interact with customers. Constantinides and Fountain (2008) stated that, social media might influence the buying behavior process of consumers. Brindha and Parameswaran (2016) agreed that, consumers are actively employing the social media platforms as a tool to validate their purchase decisions. He further advanced that, consumers are very selective especially in evaluating information obtained before purchasing. Hence, marketers have to comprehend how these social media affect consumer decision making.

The impact of internet technology and social media on consumers' decision making moved educational institutions to adapt to the new trends and developments by becoming more interactive and responsive to its students as well as prospective students on the various networks. In a study by Barnes and Mattson (2009), US universities are consistently increasing the use of social media as part of their marketing promotional programmes. This is because, students are increasingly using social media to interact with one another and access information. 
It was reported that, almost all the students of the University of New Hampshire in Durham (UHM) use at least one social media platform of which $\mathbf{9 6 \%}$ are on Facebook and $\mathbf{8 4 \%}$ on YouTube. Hence this finding is likely to apply to other universities (Capano, Deris, \& Desjardins, 2012).

In Ghana, there are a number of tertiary institutions operating in the country. It has been observed that, most of them are actively running various social networking sites with the aim of disseminating information to users. But knowing how users interact with these sites and how these sites impact their choices is very paramount. It is then very important for institutions to understand how students use their social media sites and the influence it has on their choice of one tertiary institution to the other. It is still unclear how the use of social media affects the choice of students' tertiary institutions in Ghana. This study hopes to investigate the effect social media usage has on students' choice of tertiary institutions in Ghana.

Some studies conducted by other scholars in this area of study reveal findings that seem to contradict the dominance of social media use among students. Constantinides and Stagno (2012), in their study on the impact of social media on study selection and university choice in the Netherlands concluded that, social media was ranked last by students in the list of other information channels that influence student choice of universities and courses. Per this finding among others, it is still unclear whether social media usage influence students' choice of universities looking at the increasing popularity of social media usage among young people

\subsection{Problem statement}

Consumers are currently losing interest in the content of traditional media (Stokes, 2011). People are finding it easier to switch off or ignore traditional sources of information and depend more on social media sources. Most scholars, upon the recognition of this increasing role of social media in today's world have conducted researches in areas including tertiary education and among the youths. A study conducted by Idakwo (2011) confirms that, social media use has also been adapted in the Nigerian communities as a means of communication. The study revealed that most Nigerian youths used more of Facebook as compared to other social media channels in Nigeria. These trends have therefore posed a challenge to the traditional media (Domingo \& Heinone, 2008).

However, most of the studies conducted have revealed how social media influence students' choice of universities but in developed countries such as the Netherlands and Vietnam. Dalfonso, Pratt \& Rogers (2014), in their study to find out how high school students use social media in general and in selecting universities revealed that, $68 \%$ of the students use social media in their search of colleges and universities. Constantinides and Stagno (2012), in their research to investigate the role and importance of social media on the choice of future student for a study and university comparison with the traditional university marketing channels in the Netherlands, revealed that students ranked social media last in the list of various information channels that influence students' choice of universities and course. The findings of Constantinides and Stagno contradicts the findings of Dalfonso et al (2014) and even what one would expect considering the high popularity of social media among young people. There could be a number of possible explanations that could explain Constantinidis' contradicting findings such as the lack of relevant content on social media platforms, a lack of two-way communication, no exciting and innovative applications or failure to update social media contents.

Per these contradicting findings, it is still unclear whether social media influence students' choice of universities, let alone in the developing countries, specifically Ghana.

This research, in its effort to address these research gaps seeks to apply their concepts and methodology to come out with findings in the Ghanaian jurisdiction by investigating social media usage and its effect on students' choice of tertiary institutions in Ghana - A case of students from three selected Universities in Ghana; University of Professional Studies, University of Ghana and Central University.

\subsection{Objectives of Research}

The main objective of this research is to examine how social media and its usage effects the choice of tertiary institutions of students' in Ghana.

The following specific objective guided the research:

I. Find the various social media platforms students use to search for tertiary institutions.

ii. Identify the various social media platforms students actively engage in.

iii. Examine how the use of social media influence students' tertiary institutions decision-making process.

iv. Identify other factors that influence students' choice of tertiary institutions

\section{Literature}

Students, just like other consumers go through a number of stages before arriving at a decision to choose a particular tertiary institution. Analyzing these stages, they go through will aid in determining the various media that these students are likely to employ in their search. They may include traditional media such as print media, direct mail, e-mail broadcast media (TV, Radio), physical public relations, trade fairs, family and friends. Universities, relied on these traditional marketing and recruitment tools in their promotional activities. 


\subsection{Traditional marketing and recruitment tools}

Many academic studies and literature have well identified the various conventional marketing methods used by universities. These may include advertisements such as the prints (newspaper) and broadcasts (television and radio) and public relation activities. As noted by Wernick (1991), most universities use advertising and publicity methods as their marketing and recruitment tools.

However, promotion is taking another turn from the traditional media to a more digital trend, on the grounds that the effect of web innovation on purchasers has developed to be increasingly essential concerning their choices and decisions. A research by Duffett (2017), to examine the impact of interactive social media marketing communication on young people's cognitive and behavioral attitude, revealed that social media marketing communication, an aspect of digital marketing, had a positive impact on the attitudes of teenagers. Universities, in their quest to find and convince prospective students are also no exception to this shift from traditional media to digital marketing trends.

\subsection{Digital marketing}

The emergence of digital marketing has shifted the activities of universities from the use of traditional media to an innovative and technological media. As people are giving careful consideration to the increasing decline in traditional media, others have discovered innovative ways by which digital tools can facilitate these traditional media. Digital marketing has changed the way universities utilize these traditional media in their activities in a more inventive and interactive manner. Digital packages such as smart phones and tablets for example, have introduced some interactions in advertisements. These have provided consumers with numerous alternative to choose from in order to interact fully with the adverts (Zigmond \& Stipp, 2010).

As a result of this, internet advertising has also emerged (US digital 2010, 2011). Digital marketing tools such as popup advertising, banner ads, paid search, advertising on social media and others have changed the consumers relate with information from organizations and institutions. These tools have given the rise in two-way communication which is the major driving factor in the success of these digital tools (McMahon et al., 2009). In a media comparative study 2012, it was rated that, women spend 3.26 hours per day on average compared to men who spend 2.75 hours per day on internet media.

Hence, the emergence of digital marketing has created platforms for universities to explore innovative technologies in their marketing activities which has greatly resulted in the use of social media and the various social networking sites. The impact of internet technology and social media on consumers' decision making pressed educational institutions to adjust to the new patterns and advancements by becoming more interactive and responsive to its customers thus, students on the different systems.

\subsection{Social media and social Networking Sites (SNS)}

Social media throughout the years has been transforming and emerging into the advancement of a new media hence, the ascent in progressing talks about a universal definition of social media (Solis, 2007). The emergence of social media has provided improved ways of accessing information hence changes in the ways universities recruit and select prospective students. According to Kaplan and Haelein (2010), social media is a group of internet-based applications that build on the technologies of Web 2.0 allowing the creation and exchange of usergenerated content. Social media can also be defined as a marketing tool used to identify customers and prospects in ways that were unimaginable (Chapman 2013). It is evident that according to these authors, social media can include; virtual game worlds (World of Warcraft), virtual social worlds (second life), social networking sites (Facebook, Twitter), blogs, content communities (YouTube) and collaborative projects (Wikipedia) (Kaplan \& Haelein, 2010).

A recent study by Insites (2011) shows that, currently in Europe, 73percent or around 347 users are using social media. Brindha and Parameswaran (2016) agreed that, consumers are actively employing the social media platforms as a tool to approve their purchase choices. He additionally propelled that, consumers are very selective especially in assessing data obtained before purchasing.

Social Networking Sites (SNS) according to Weinberg (2009) are general terms for sites used to connect users with similar interest and foundations. These sites are platforms that help users to connect with others hence forming strong ties (such as family and friends) and weak ties (such as acquaintances) such as Twitter, MySpace.com and Facebook. Boyd and Ellison (2007) disclosed that, social media platforms possess common elements across most of them thus; (1) Creation of customized public or semi-public profile within a bounded system, (2) A list of other users with whom a connection is shared, and (3) View and explore connections and those made by others within the system. As detailed by Capano, Deris, and Desjardins (2012), it was unveiled that almost all the students of the University of New Hampshire in Durham (UHM) at least use one social media platform of which 96 percent are on Facebook and 84 percent on YouTube. Hence this finding is likely to apply to other universities. Social media can also be online media sites such as Facebook, LinkedIn, and Twitter as well as video sharing sites such as YouTube (West, 2011). 
A recent study conducted by Dalfonso, Pratt, and Rogers (2014) found out that, students who view social media sites for their college/university choices consider Facebook mostly followed by YouTube and the Twitter. It was also advanced that 33\% of students visited the school's Facebook site, $20 \%$ visited the school's YouTube site and $17 \%$ also visited the Twitter site of the school once a week or more. Young (2008) pointed out that, it is very essential for universities to use online social platforms like Facebook for the purpose of academics. This called for the assertion made by Thompson (2007) that, students who are entering colleges and universities are considered digital natives due to their frequent engagement in social networking activities.

Evaluations of these literature Cleary shows that the advent of digital media has a great influence in the decision process of students who are trying to decide on the best university that will give them the optimal satisfaction.

\subsection{Consumer Decision Making Process}

The consumer's purchase decision is a vital tool used by organizations to determine the process consumers go through before arriving at a decision. According to Kotler and Keller (2009), the consumer's decision making process model comprises of five stages: need recognition, information search, and evaluation of alternatives, purchase decision and post-purchase evaluation. This model will help examine how the use of social media influences students' choice of tertiary institutions. Silverman (2001) posits that, it is very important to examine the various factors that turn prospects into consumers.

2.4.1 Need recognition stage

This stage sets in from the very moment where the consumer realizes a problem to be solved or a need to be satisfied. Need recognition is when consumers are brought to notice about an unfulfilled need (Hoyer \& MacInnis, 2010).

\subsubsection{Information search stage}

This is the stage where the consumer then seeks for information about ways to satisfy the need thereby at this stage, the consumer is more receptive to any information pertaining to the product or service. The magnitude to which a consumer searches for needed information might depend on the consumer's level of information currently and the perceived value of additional information (Pradhan, 2009). The consumers are exposed to necessary information through marketing activities directed at them by marketers and other personal sources of information. The information sources can be divided into two types: internal and external. Internal search centers on the former information held by the consumer and experiences which will result in future behavior that the consumers will be likely to take (Solomon, Bamossy, \& Askgaard, 2012). These marketing activities may include advertising, personal marketing sales promotion, public relations and direct marketing. Personal sources such as peer influences, family, word of mouth communication and other significant others.

The external search also includes word of mouth, campus visit, trial and online social networking and social media (Kardes, Cronley, \& Clinc, 2011).

\subsubsection{Evaluation of alternatives}

This is the stage where consumers consider the relative importance of each attribute of the product-service mix (Reid \& Bojanic, 2009). Consumers after seeking information, form a set of alternatives to be considered in order to make the final decision. Consumers form beliefs which guides their perception, attitudes and their choice (Sternthal \& Craig, 1982). These beliefs will aid them in choosing the alternative that best fit their needs.

\section{2..4.4 Purchase Stage}

After alternatives are weighed, the purchase choice or decision is made. At this stage the consumer intends to buy the product or service. But before the consumer settles, there are two main factors that will trigger their choice for a particular alternative via; attitude of others and unanticipated situational factors. The extent to which another person's negative attitude towards an alternative or reluctance of the person to meet factors that support the purchase intention is termed as attitude. Whereas unanticipated situational factors are factors that arise unexpectedly and out of the control of the consumer to change consumer's purchase intention for example, as the consumer intends to buy a particular alternative, an unexpected urgency to buy a different alternative may arise (Kotler \& Keller, 2009). The choice is influenced by information obtained by the consumer from various sources (Hawkins \& Mothersbaugh, 2010).

\subsubsection{Post-purchase behavior}

Finally, the consumer decision making process ends with the post-purchase behavior of consumers. This is the evaluation of the performance of the purchased alternative and satisfaction derived from experiencing it. Two outcomes are derived from this stage; satisfaction or dissonance. Consumers start to search for information and evaluate other alternatives which will trigger new decisions as and when they experience dissonance (Sternthal \& Craig, 1982).

However, Randall Chapman propounded a more direct model which explains the process prospective college students go through in selecting a particular college to attend. The next model explains the college selection process of prospective college students and how social media is able to influence their choice. 


\subsection{Randall Chapman's College Selection Process}

Randall Chapman in the 1986 proposed the theory of college selection process which explains the selection process students go through to select a particular college. The model is divided into five stages: 1) pre-search behavior, 2) search behavior, 3) application decision, 4) choice decision, and 5) matriculation decision.

\subsubsection{The pre-search behavior}

This stage could begin at the elementary/high school. This stage involves when students first come to recognize the possible value of tertiary level education. It could be dependent on parent's influence in conversations with prospective about going to college and also peer conversions. As stated by Chapman R (1986), the pre-search stage is the most difficult stage to study as the beginning of the process differs from one student to the other.

\subsubsection{The search behavior}

This stage explains the active process by which the student exposes him or herself to information from various institutions. In the search stage, the student also depends on information from other relevant sources to add to information retrieved from the specific universities or colleges. These other sources may be from friends, teachers, college alumni and family (Anctil, 2008). Certain students also decide to visit campuses of the colleges. The students then weigh the benefits of the information received from the various sources such as; campus experience, academic experience, social networking sites and potential for future career success. As these benefits are weighed, the student is able to finalize the specific colleges to be considered for admissions. Due to the frequent interactions and involvement by students in social networking sites (Schroeder \& Greenbowe, 2009), students are most likely to search for all kinds of information even when they need to decide on colleges and universities to attend. Hence, Thompson (2007) considers students as digital natives.

\subsubsection{Application decision}

The third, fourth and fifth stages are closely linked together (Chapman R., 1986). The application decision stage sets in after the student has decided the specific colleges to consider for admission. At this stage, the student goes through the process of applying to a school. The student considers a number of factors as he or she goes through the application process such as; campus life, cost of attendance, and academic programs. Students visit various campuses of the considered schools to have a face-to-face interaction with campus life, visit social sites of the schools such as the school's Facebook page, Twitter page and YouTube sites to experience the various activities that goes on. The student then waits for acceptance notification of the admission from the institutions.

\subsubsection{The choice decision}

This stage takes root once the student receives an acceptance notification from the institution regarding the admission. During this stage, the student weighs the attendance of the various institutions from which admissions were accepted. Hence, the student searches for information pertaining to the institutions (visiting the institution's websites, social networking sites and word of mouth communication) and also seek for additional information concerning courses offered and financial aid in order to make an informed decision about the school to attend. Finally, the student chooses the specific college or university he or she will attend.

\subsubsection{The matriculation decision}

This stage sets in once the student makes up his or her mind as to the specific college or university to attend. This is the stage where the students officially enroll and begin classes.

These models and concepts have been used by a number of scholars in their various studies. Constantinides \& Stagno (2012) in their research in the Netherlands, applied the concept of traditional media as a source of information among students, which include friend choice, family's choice, proximity to parents good and affordable word of mouth and university website, when selecting a university. These concepts served as other alternatives for which social media could be compared with. It was revealed that students ranked these traditional media first over social media. This finding was however revealed in the Netherlands and might not apply to other countries.

\subsection{Empirical Literature.}

A study conducted by Maguire (2011) in Norway, using a quantitative method, surveyed 2100 high school seniors to find out how they rely on social media to narrow down college options. It was advanced that $57 \%$ of the students watched a YouTube video created by the school and 53\% read posts about a school on a social networking site. It was therefore concluded that, students also use the social media sites to source for information in evaluating schools. However, in a study by Constantinides and Stagno (2012) in the Netherlands, students ranked social media last in the list of various information channels that influence students' choice of universities and course. This finding is in contrast with the study by Maguire (2011) considering the high usage and popularity of social media among students.

Dalfonso, Pratt and Rogers (2014) revealed that, $68 \%$ of students use social media in their research of colleges and universities although $70 \%$ of the students said that, social media had a moderate influence on their college/university search. A study by Dao and Thrope (2015) reported the factors that influence Vietnamese students' choice of university in the context where the effect of globalization and education reform are changing 
Higher Education. Using the survey design, it was revealed that nine key factors influence student decisions in order of significance which are; facilities and services, programme, price, offline information, opinions, online information, ways of communication, programme addition and advertising. These findings revealed that social media had a moderate impact on students' choice of colleges and universities.

It was also revealed by Capano, Deris, and Desjardins (2012) that, almost all the students of the University of New Hampshire in Durham (UHM) at least use one social media platform of which 96 percent are on Facebook and 84 percent on YouTube. Hence this finding is likely to apply to other universities however, the findings of Constantinides and Stagno, 2012 say otherwise.

Other studies in the hospitality industry such as Varkaris and Neuhofer (2017) uncovered how social media influence consumer behavior during hotel decision making using an exploratory design. It was observed that, social media transform the consumers' hotel decision journey by influencing the way consumers search, decide and book hotels in Austria.

The study by Maguire (2011), Dalfonso, Pratt and Rogers (2014) and Capano, Deris, and Desjardins (2012) all adopted the quantitative approach and revealed that students' were influenced by social media in their selection of universities and colleges. Capano, Deris, and Desjardins (2012) furthermore added that, these findings are likely to apply to other universities. However, these findings were limited to their respective countries of study and hence could not be applied to other countries due to differences in factors such as culture and technology.

\section{Methodology}

For the purpose of this research, the quantitative research methodology was used because the main objective of this research was to examine the effect of the use of social media on students' choice of tertiary institutions and since a quantitative research methodology supports the view of measuring the effect of one variable on the other and also allows the generalization of results (Creswel, 2012) hence the choice of this type of research approach. According to Malhotra (1999), Quantitative Research methodology describes a methodology that seeks to quantify the data and typically, applies some form of statistical analysis however according to Fraenkel \& Wallen (2003), quantitative research methodology can be classified as either descriptive or experimental research design. A descriptive research approach was employed to establish the relationship between the two variables as stated in the research topic.

\subsection{Sample size}

According to Malhotra (2010), the minimum and appropriate sample size for a study is 200 respondents. Hence,A total number of 210 respondents which were evenly drawn as 70 respondents from each of the three (3) selected universities.

\subsection{Instrumentation}

The data collection instrument used for this study was questionnaire. Kumar (2011) explains that a questionnaire is the basic research tool made up of a formalized set of questions which are drawn in relation to the research problem and is used to obtain information from the respondents which is in tend used to find solutions to the identified research problems.

Questionnaire was chosen for this study because, according to Saunders et al, (2009), using questionnaire as a data collection instrument is efficient especially when collecting data from a large number of people because the respondents will be asked to respond to the same set of questions hence avoiding bias in data collection process.

Saunders et al (2009) describes that there are two types of questionnaires. These are; self - administered questionnaires and interviewer - based questionnaires. The study used self-administered questionnaires which were delivered by hand to the respondents in their various campuses. According to Saunders et al (2009), conducting self - administered questionnaires is easier and cheaper than the interviewer - based questionnaires and it also allows to survey a large number of respondents. The questionnaire contained open-ended questions and was divided into three sections of which section A examined personal data of respondents, section B, questions on various media used by students and adapted from previous studies conducted by Constantinides \& Stagno (2012), Barnes \& Mattson (2009) and Fotis et al (2012); while section C looked at the influence social media has on students' decisions which was also adapted from studies of Bhayani (2015), Tereza (2013) and Khatib (2016).

\subsection{Data Analysis}

For the purposes of establishing a clear outcome, the data collected from respondents were entered and coded using the Microsoft Excel.

\section{Analysis and Discussion of Findings}

\subsection{Demographics}

The responses of respondent with regards to their demographic data. From the survey, it was evident that $56.2 \%$ 
of the participants were Males and $43.8 \%$ of the participants were females. This however showed that males were the dominating population in the study. The study showed that, $43 \%$ of the respondents were between the ages of $16-20$ years. $57 \%$ of them were within the age category of $21-25$ years. For respondents' tertiary institutions, a number of 70 respondents each for UPSA, University of Ghana and Central University responded to the survey, amounting to $33.33 \%$ each.

Table 1. Demographic Data

\begin{tabular}{|l|r|r|}
\hline & Frequency & Percentage \\
\hline Gender & 118 & \\
\hline Male & 92 & $56.2 \%$ \\
\hline Female & & $43.8 \%$ \\
\hline & & $\mathbf{1 0 0 \%}$ \\
\hline Age & 90 & $43.0 \%$ \\
\hline $16-20$ & 120 & $43.0 \%$ \\
\hline $21-25$ & & $57.0 \%$ \\
\hline & & $\mathbf{1 0 0 \%}$ \\
\hline University & 70 & $33.33 \%$ \\
\hline UPSA & 70 & $33.33 \%$ \\
\hline UG & 70 & $33.33 \%$ \\
\hline CENTRAL & & $\mathbf{1 0 0 \%}$ \\
\hline
\end{tabular}

\subsection{Discussion of Findings}

The main purpose of the study was to assess the usage of social media and its effect on students' choice of tertiary institutions in Ghana. The study made use of descriptive survey design and also adapted a quantitative approach of assessing and analyzing the data gathered from a number of 210 respondents. The study targeted students from three selected universities in Ghana namely, University of Professional Studies, University of Ghana and Central University. However, convenience sampling technique was used to select the required number of respondents for the study. In order to fulfill the main intent of the study, four (4) specific objectives were set to guide the research in order to come up with relevant findings that will seek to thoroughly answer the main research objective. The results for these specific objectives have been elaborated below.

The first objective sought to find the various social media platforms students use to search for tertiary institutions. From the analysis, it was clear that, even though majority of the respondents first heard about their university from a friend or a family member, most of them nevertheless still relied on social media platforms for information on tertiary institutions. The data analysis revealed that, University website was the most used platform for information search with a percentage of 172 responses as shown in table 4.2.3. The analysis also revealed that that majority of the responses which constitute $89 \%$ seek for information about the university while $77 \%$ seek for course information. Perhaps these kinds of information of information explains why students relied the most on university website for information. However, 50\% of the responses indicated they also relied on Facebook followed by blogs, with a response percentage of 24 . These findings however require further studies since future students might be heavy users social media platforms as compared to these present on or otherwise. 
Table 2 Social media sites respondents explored when selecting their tertiary institutions

\begin{tabular}{|lccl|}
\hline & Response (N) & Percentage (\%) & Percent of cases(\%) \\
\hline LinkedIn & 4 & $1.29 \%$ & $4.00 \%$ \\
\hline Twitter & 16 & $5.14 \%$ & $16.00 \%$ \\
\hline Google+ & 18 & $5.79 \%$ & $18.00 \%$ \\
\hline YouTube & 12 & $3.86 \%$ & $12.00 \%$ \\
\hline Facebook & 50 & $16.08 \%$ & $50.00 \%$ \\
\hline Instagram & 11 & $3.54 \%$ & $11.00 \%$ \\
\hline WhatsApp & 4 & $1.29 \%$ & $4.00 \%$ \\
\hline Blogs & 24 & $7.72 \%$ & $24.00 \%$ \\
\hline University Website & 172 & $55.31 \%$ & $172.00 \%$ \\
\hline Total & $\mathbf{3 1 1}$ & $\mathbf{1 0 0 . 0 0 \%}$ & $\mathbf{3 1 1 \%}$ \\
\hline
\end{tabular}

The second objective sought to find the various social media platforms students actively engage in. The outcome of the study demonstrated that majority of respondents were very active on WhatsApp with the highest response rate of $79.21 \%$, followed by LinkedIn with $67.74 \%$ then Facebook with a percentage of 50 as shown in table 4.2.5. This can be clearly supported with the fact that, majority respondents testified that they spend over two hours, that is, $65.69 \%$ on Whatsapp only. The study also revealed that even though majority of the respondents were active and relied heavily on university website for information, they spent least time on university website since the analysis revealed that majority of the respondents with $72.45 \%$ spend only up to 30 minutes on their school's website as shown in figure 4.2. Respondents however occasionally active on Twitter, Instagram and YouTube. These same candidates indicated that they were occasionally active on Instagram, and YouTube. Others indicated the fact that they were very active on Google+ with $41.84 \%, 67.74$ said they were very active on LinkedIn, and $48.39 \%$ also said they were very active on Blogs.

The third objective sought to examine how the use of social media influence students' tertiary institution decision making process; and the outcome that emerged revealed as shown in table 4.2.1 that, recommendation from friends and family was what played a role the most in helping students realize the possible value of tertiary level education with a percentage of 50 , followed by the interactions on social media platforms with $18.1 \%$ and school councilor's advice with $13.33 \%$. Even though contents of university social media sites also play a role in the pre-search behavior of the college decision making process, it is not as significant as compared to the above listed based on the data analysis. The search behavior stage explains the active process by which the student exposes him or herself to information from various institutions (Chapman R., 1986). Due to the frequent interactions and involvement by students in social networking sites (Schroeder \& Greenbowe, 2009), students are most likely to search for all kinds of information even when they need to decide on colleges and universities to attend. The results demonstrated that $172 \%$ of the response resort to the university's website. $50 \%$ of the respondents resort to Facebook, 24\% resort to blobs and 18\% resort to Google+ for information as shown in table 4.2.3. This however indicates that the university's website, followed by Facebook, blogs and Google + are the dominant social media sites students explore when selecting their tertiary institution. The application and the choice decision stages are closely linked together. They set in after the student has decided the specific colleges to consider for admission. The student considers a number of factors visit social sites of the schools such as the school's Facebook page, Twitter page and YouTube sites and school website to experience the various activities that goes on (Chapman R., 1986). The data analysis revealed as shown in figure 4.3 that Websites was the dominating factor that influence students in the application and choice decision stage; The study confirmed based on the assertions on websites that, $51.49 \%$ of the respondents strongly attest that their universities' info on their website affected their choice of university selection. $58.59 \%$ also indicated that the website displays about their university influenced their choice. $58.2 \%$ of the respondents also attested that their universities profile on the Websites have enhanced their choice of university selection. The analysis also revealed that followed by websites, students $40.21 \%$ and $34.02 \%$ agreed and strongly agreed respectively showing that students were also motivated to choose their university because of activities on content sharing sites such their profile on LinkedIn. Blogs on the other, were the least factors that influenced students at the application behavior. The matriculation decision is the stage where the students officially enrolls and begin classes. 


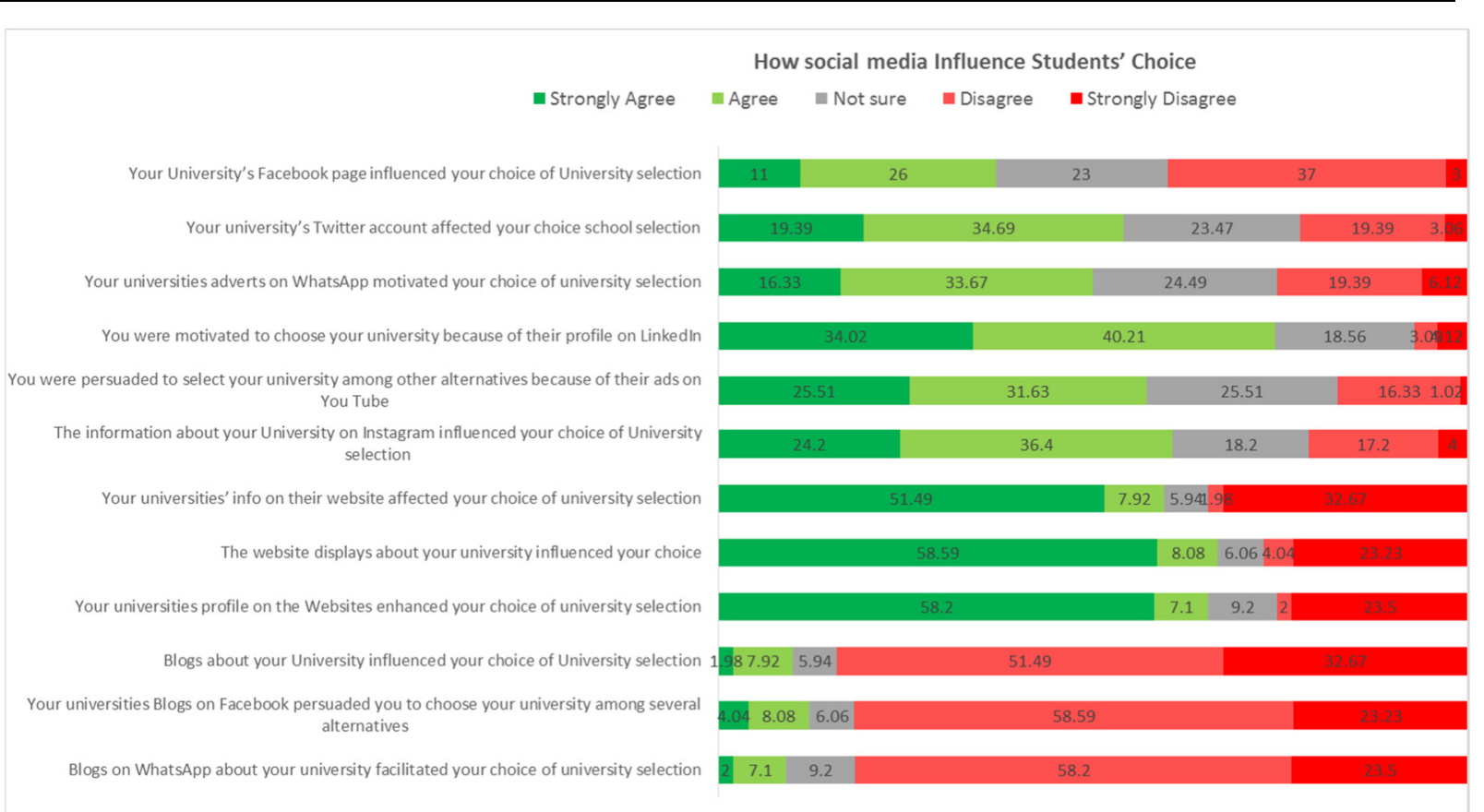

Figure1. How social media influence student's choice of tertiary institution.

The fourth objective sought to identify other factors that influence students' choice of tertiary institutions. Even though the study aims at examining the usage of social media and its effect on students' choice, it also sought to consider other choice factors aside social media which were likely to influence students' choice of tertiary institutions in order to add up to existing knowledge that might help find possible areas that may require further studies. The responses that emerged at the end of the study indicated academic reputation, friends and family members and financial aid were the dominating factors that influence students' choice. Even though other factors such as mass media and newspaper advertising according to Lee and Chatfield (2015) are factors that influence student choice, based on the analysis, $46.88 \%$ of the respondent detest the reason that newspaper advertising was a factor that influenced their choice of tertiary institution. $47.42 \%$ of the respondents also confirmed that Mass Media, that is, television and radio was not a factor that influenced their choice decisions.

\section{Conclusion}

The following conclusions were made based on the findings of the study:

- Even though majority of the respondents first heard about their university from a friend or a family member, most of them nevertheless still relied on social media platforms for information on tertiary institutions.

- University websites is the most used platform for information search.

- Majority of the students seek for information about the university and course information.

- Majority of students are very active on WhatsApp, LinkedIn and Facebook.

- Recommendation from friends and family plays the most role in helping students realize the possible value of tertiary level education with a percentage of 50 , followed by the interactions on social media platforms in the pre-search behavior stage.

- Universities' info on websites, website displays about universities, universities profile on their Website enhance students' choice of university selection.

- Academic reputation, friends, family members and financial aid are the dominating other factors that influence students' choice.

\subsection{Recommendations}

- It was recognized in the study that social media platforms like Instagram, Twitter, and YouTube attracted lesser and minimal usage. The researcher however recommends that universities should endeavor to explore other social media platforms which students are actively engaged such as LinkedIn, WhatsApp and blogs that will seek to portray and display the schools' image.

- It was identified that, university websites was the most used platform for information search hence, universities should keep their website contents up to date exploring various academic information to continuously gain audience.

- Since the study revealed that students were very active on WhatsApp, it is recommended that universities 
should develop online word of mouth programs and also engage in viral marketing through WhatsApp hotline on university websites, to encourage alumni and others to share their experience and life in the various universities.

- Since one of the dominating other factors that influence student choice is academic reputation, tertiary institutions can take advantages of social media platforms such as LinkedIn to build professional profiles, organize international online academic activities on their websites that will increase the reputation of the school.

\section{References}

Anctil, E. J., 2008. Selling higher education. ASHE Higher Education Report, 34(2).

Anon., 2016. Internet World $\quad$ Stats. Available at: www.internetworldstats.com/2016

Anon., 2016. Research and Markets: Global Mobile Apps \& Social Networks. [Online] Available at: socialnetworkingwatch.com/2012/11/research-and-markets-global-mobile-apps-socialnetworking.html

[Accessed 02 October 2017].

Barnes, N. G. \& Mattson , E., 2009. Social Media and College Admissions: The First Longitudinal Study. Dartmouth (USA): University of Massachusetts, Center for Marketing Research.

Boyd, D. M. \& Ellison, N. B., 2007. Social Network Sites: Definition, history and scholarship. Journal of Computer-Mediiated Communicatiob, 13(1).

Briggs, S., 2006. An exploratory study of the factors influencing undergraduate student choice: The case of Higher Education in Scotland. Journal of Higher Education, 31(6), pp. 705-722.

Brindha, N. \& Parameswaran, R., 2016. Consumer Decision-making Process in Social Media Platform. Global Journal for Research Analysis, 5(12), pp. 60-81.

Burns , N. \& Grove, S., 2003. Understanding nursing research. Philadelpihia: Saunders Company.

Capano, N., Deris, J. \& Desjardins, E., 2012. Social networking usage and grades among college students. [Online] Available at: http://www.unh.edu/news/docs/UNHsocialmedia.pdf

Chapman, D. W., 1981. A model of student college choice. Journal of Higher Education, 52(5), pp. 490-505.

Chapman, R. G., 1986. Toward a theory of college selection: A model search and choice behavior. Journal of Advances in Consumer Research, 13(1), pp. 246-250.

Constantinides, E. \& Fountain, S. J., 2008. Web 2.0: Conceptual foundations and marketing issues. Direct, Data and Digital Marketing Practice, 9(3), pp. 231-244.

Constantinides, E. \& Stagno, M. Z., 2012. Higher Education Marketing: A study on the impact of social media on study selection and university choice. International Journal of Technology and Education Marketing, Volume 21, pp. 41-58.

Creswel, J. W., 2012. Educational Research: Planning, conducting, and evaluating quantitative and qualitative research. Boston: Pearson.

Dalfoso, J. D., Pratt, A. \& Rogers, G., 2014. Digital, Social, Mobile: 2014 Social admissions report. [Online] Available at: http://www.uversity.com/downloads/presentations/2014-Social-Admissions-Report-

Dao, T. N. M. \& Thorpe, A., 2015. What factors influence Vietnamese students' choice of university. The International Journal of Education, 29(5), pp. 666-681.

Domingo, D. \& Heinone, A., 2008. Weblogs and Journalism: A Typology to Explore the Blurring Boundaries.”, , Nordicom Review, 29(1), pp. 3-15.

Duffett, R. G., 2017. Influence of Social Media Marketing Communication on young consumers' attitudes. Young Consumers, 18(1), pp. 19-39.

Fotis, J., Buhalis, D. \& Rossides, N., 2012. Social Media Use And Impact During The Holiday Travel Planning Process. Vienna, Austria.: Springer-Verlag.

Garrison, B., 1996. Successful Strategies for Computer-Assisted Reporting. Mahwah NJ(USA): Lawrence Eribaum Associates.

Hawkins, D. \& Mothersbaugh, D. L., 2010. Consumer Behaviour: Building marketing strategy. 11th ed. New York: McGraw-Hill Irwin.

Heath, R., 2007. How do we predict advertising attention and engagement? s.1.:School of Management University of Bath Working Paper.

Hoyer, W. \& MacInnis, D., 2010. Consumer Behaviour. 5th ed. London: South-Western Cengage Learning.

Idakwo, L., 2011. The Use of Media Among Nigeria Youth. [Online] Available at: http://www.slideshare.net/goldlami/the-use-of-social-media-among-Nigeriayouth2 Insites, 2011.

[Online] Available at: from http://www.iie.org/en/Research-and-Publications/Open-Doors.

[Accessed 12 April 2013]. 
Jankowicz, A., 2005. Business Research Projects. 4th ed. London: Thompson Learning.

Kaplan, A. \& Haelein, M., 2010. Users of the World: The Challenges and Opportunities of Social Media. Journal of Bussiness Horizons, 53(1), pp. 59-68.

Kardes, F. R., Cronley, M. L. \& Clinc, T. W., 2011. Consumer Behaviour. s.1.:South-Western.

Keller, K. L., 2013. Strategic Brand Management. Fourth ed. Harlow(England): Pearson Education Limited.

Kotler, P. \& Keller, K., 2009. Marketing Management. 13th ed. s.1.:Pearson Education.

Levy \& Lemeshow, \&., 1999. Sampling Of Population : Methods and Application. In: Sampling Of Populations. New York: John Wiley \& Sons, p. 6.

Maguire, J. \& Maguire, L., 2011. Maguire Associates. [Online] Available at: Fastweb.com/Social tools factors in college enrollment decisions

Malhotra, 2010. In: s.1.:s.n., p. 377.

Malhotra, N. K., 2010. Introduction: Analysing accumulated knowledge and influencing future research. s.1.:Emerald Group Publishing Ltd..

N Gizem, K., Secil, K. \& Evrin, E., 2013. Social Media From The Perspective of Diffusion of Innovation. $A$ Multidisciplinary Journal of Global Macro Trends .

Phillip, J. \& Melewar, T. C., 2006. The relationship between corporate website and brand equity. A conceptual framework and research agenda.. International Journal of Market Research. , 48(5), pp. 575-599.

Pradhan, B., 2009. Retailing Management. 3rd ed. s.1.:Tata McGraw-Hill Education.

Reid, R. \& Bojanic, D., 2009. Hospitality Marketing. s.1.:John Wiley \& Sons.

Richardson, 2005.

Richardson, J. T., 2005. Instruments for obtaining students' feedback: A review of the literature, Assessment and evaluation in higher education. 30(4), pp. 387-415.

Safko, L. \& Brake, D. K., 2009. The social media Bible. Tactics, Tools and Stategies for business success. NJ, USA: John Wiley and Sons.

Salant \& Dillman, 1994. How to conduct your own survey. New York: s.n.

Saunders, M., Lewis, P. \& Thornhill, A., 2009. Research Methods for Business Students. Fifth ed. London(England): Pearson Education Limited.

Schroeder, J. \& Greenbowe, T., 2009. The Chemistry of Facebook: Using Social networking to create an online community for the organic chemistry laboratory. Innovative Journal of Online Education, 5(4), p. 54.

Silverman, B., 2001. Implications of Buyer Decision Theory. International Journal of Human-Computer Studies, p. 55.

Solis, $2007 . \quad$ B., The Social Media Manifesto. [Online] Available at: (http://www.briansolis.com/2007/06/future-of-communications-manifesto-for/ [Accessed 16 March 2013].

Solomon, M., Bamossy, G. \& Askgaard, S., 2012. Consumer Behaviour: A European Perspective. Upper Saddle River, N J: Perarson Prentice Hall.

Sternthal, B. \& Craig, C. S., 1982. Consumer Behaviour: An Information Processing Perspective. Eaglewood Cliffs, N J: Prentice Hall Inc.

Stokes, R., 2011. Emarketing: The Essential guide to Digital marketing. 4th ed. s.1.:Sarah Blake and Quirk Education.

Strauss, J. \& Frost, R., 2001. E-marketing. New Jersey: Prentice Hall .

Thompson, J., 2007. Is Education 1.0 ready for Web 2.0 students?. Innovative Journal of Online Education, 3(4), p. 6.

Thornhill \& Saunders, a., 2003. In: s.1.:s.n., p. 486.

Varkaris, E. \& Neuhofer, B., 2017. The influence of Social Media on consumers' hotel decision journey. Journal of Hospitability and Tourism Technology, 8(1), pp. 101-118.

Watch, B., 2012. State of the Media: The Social Media Report. [Online] Available at: http:/www.brandwatch.com/2012/12/how-we-use-social-highlights-from-the-social-mediareport-2012/

Weber, L., 2009. Marketing to the Social world: How digital customer communities build your business. 2 nd ed. NJ, USA: John Wiley and Sons.

Weinberg, T., 2009. The New Community Rules: Marketing on the Social Web. Sebastopol: O'Reilly Media Inc.

Wernick, A., 1991. Promotional Culture:Advertising,Ideology and Symbolic Expression. London: Sage Publications.

West, C., 2011. You're on Facebook.....Now What?. Journal of Educator, 20(3), pp. 88-92.

Zarella, D., 2010. The Social Media Marketing Book. Carlifornia: O'Reilly Media.

Zigmond, D. \& Stipp, H., 2010. Assessing a new advertising effect. Journal of Advertising.

Zynman, S., 1999. The End of Marketing As We Know It. New York: Harper Business. 